\title{
Efficiency of the Slovak forestry in comparison to other European countries: An application of Data Envelopment Analysis
}

\author{
Miroslav Kovalčík \\ National Forest Centre - Forest Research Institute Zvolen, T. G. Masaryka 2175/22, SK - 96092 Zvolen, Slovak Republic
}

\begin{abstract}
Efficiency improvement is important for increasing the competitiveness of any sector and the same is essential for the forestry sector. A non-parametric approach - Data Envelopment Analysis (DEA) was used for the assessment of forestry efficiency. The paper presents the results of the efficiency evaluation of forestry in European countries using DEA. One basic and two modified models (labour and wood sale) were proposed, based on available input and output data from Integrated Environmental and Economic Accounts for Forests and specific conditions of forestry also. The sample size was 22 countries and the data for 2005-2008 was processed. Obtained results show average efficiency in the range of $69-90 \%$ (depending on the model). Based on the results of the analysis following can be concluded: Slovak forestry achieved under average efficiency in comparison to other European countries, there were great differences in efficiency among individual countries; state of economy (advanced countries and countries with economy in transition) and region did not influence the efficiency statistically significant.
\end{abstract}

Key words: efficiency assessment; Data Envelopment Analysis; forestry sector; labour model; wood sale model

Editor: Miroslav Hájek

\section{Introduction}

In the early 1990s, the states of Middle and Eastern Europe began to transform their economy to a marketoriented. This fact influenced whole economy as well as the forestry sector. Until 1990, the state managed all forests in Slovakia central planed the wood flow from producers to consumers. After 1990 due to restitution, the forestry sector was fragmented with increasing of the number of forest land owners and related decentralization of production activities. The process of forest land restitutions has not been completed yet. It stagnates mainly at small private forest owners. Other problem regarding to great number of small forest land owners and resulting land communities without legal subjectivity, is the restricted use of financial resources from the European funds and low interest to associate the small forest land owners. All these facts have influenced efficiency of forestry in a serious way. Therefore the question is how efficient is the Slovak forestry in comparison to other European countries?

Measuring and improving efficiency is important to encourage progress in any organization (Sowlati 2005). It has received increasing attention also in the forestry sector. Time and capital are essentially the largest inputs within forestry. In other words, forestry is a capital-inten- sive activity with very long production periods. This capital-intensity is fundamentally reflected in the efficiency analysis of forestry investments and in the evaluation of forest properties (Saastamoinen \& Matero 2006). Other sector specific problems of performance measurement are: uniformity of product and production capacities within wood production, forests are ecosystems as well as production systems, product and benefit multiplicity, joint production and multiple use, geographical and biological variety and others.

Efficiency is in general defined as a quotient or ratio of outputs being produced to inputs being needed (Oesten $\&$ Roeder 2001). This quotient of aggregated outputs to aggregated inputs [1] is needed to determinate the efficiency for each production unit (Hoffmann 2006).

$$
P_{k}=\frac{\text { Aggregated outputs }}{\text { Aggregated inputs }}
$$

where: $P_{k}$ - efficiency of the production unit $k$.

Different methods and approaches have been used to evaluate the efficiency of production process. They are based on different principles and functions. In general, the evaluation of the efficiency is based on a production function, which specifies the relationship between the observed inputs and outputs. The production frontier 
indicates the maximum output that is possible to be produced under different input's combination and the ratio of the unit's output to the maximum possible outputs gives the measured efficiency. Those approaches, in which the production function is either known or estimated statistically, are the parametric approaches. The disadvantages of these parametric approaches are that an explicit functional form of inputs and output is needed. General known are also the principles, in which the performance is being evaluated on the ground of a ratio of received revenues to spent costs (Cost Benefit Analysis). In many situations, the functional form of the production function is not known or it is difficult to estimate. Therefore it is desirable to compare single production units to real achievable production. This is possible by using nonparametric approaches. Farrell's method of computing the efficient function from a set of observation was the foundation for non-parametric approaches in measuring efficiency and productivity. In the non-parametric approaches, no assumptions are made about the form of the production function. Instead, a best practice function is built empirically from the observed inputs and outputs. This is the main advantage of this group of methods (Sowlati 2005). Detailed classification of different methods and approaches for evaluation of efficiency describe Schefczyk \& Gerpott (1994). Evaluation methods can be systematized on the basis of three main criteria: 1 . deterministic versus stochastic character of method, 2. parametric or non-parametric methods and 3. evaluation of efficiency by using mathematical programming models versus statistical approaches. Choice of the appropriate method and the way of the efficiency evaluation depend mainly on availability of data and the form of variables to be evaluated.

Although the first paper written on DEA appeared in 1978 , and it has been applied in different areas since then, the forestry community has been slow in adapting the method and applying it to measure the efficiency of forest related activities (Sowlati 2005). There are few applications of DEA in forestry and forestry-related sectors, e.g. Kao \& Yang 1991, 1992; LeBel 1996; Shiba 1997; LeBel \& Stuart 1998; Yin 1998, 1999; Kao 2000; Hanninen \& Viitala 2003; Bogetoft et al. 2003; Nyrud \& Baardsen 2003; Hoffmann \& Sekot 2004; Hofmann 2006; Sekot \& Hoffmann 2007; Kovalč́́k 2007.

This explorative study assessed efficiency of forestry in European countries by using non-parametric approach - Data Envelopment analysis (DEA), compared the Slovak forestry efficiency according to other European countries and analysed differences in efficiency of individual countries or groups of countries.

\section{Methods and material}

\subsection{Models of Data Envelopment Analysis being used}

Data Envelopment Analysis (DEA) is a relatively new technique in productivity management for measuring efficiency of many homogenous entities. It is a linear programming method that can consider many inputs and outputs simultaneously to measure the relative efficiencies of the units to be evaluated, termed in this case decision making units (DMUs). In particular, the DEA models do not require the assignment of predetermined weights to input and output factors. In contradiction to the parametric approach, DEA does not require any assumptions about the production form. DEA models have been effectively applied for measuring the relative efficiency of the production units in many fields (Liu 2005).

The DEA approach was developed by Charnes et al. (1978) being called Charnes-Cooper-Rhodes (CCR) model. This model produces an efficiency frontier based on the concept of Pareto optimum under the assumption of constant return to scale. Later, Banker et al. (1984) developed the Banker-Charnes-Cooper (BCC) model that produces variable returns to scale efficiency frontier to measure the technical efficiency.

The use of both models allows the measurement of scale efficiency: for each production unit scale efficiency is the ratio between CCR and BCC efficiencies. Identical CCR and BCC results imply that the unit operates at an optimal scale. Main problem of non-parametric approaches is to find out the corresponding weights by using linear programming in order to maximize the ratio. To determine the efficiency of $s$ units $s$ linear programming problems must be solved to obtain the value of the weights $\left(c_{i}\right)$ associated with inputs $\left(x_{i}\right)$, as well as the value of weights $\left(p_{j}\right)$ associated with outputs $\left(y_{j}\right)$. Assuming $m$ inputs and $n$ outputs and transforming the fractional programming model into a linear programming model (Diaz-Balteiro et al. 2006). Let the unit $k$ to be evaluated on any trial be designated as unit $o$ where $o$ ranges over $1,2 \ldots s$. The input orientated CCR model [2] can be formulated as follows (Charnes et al. 1978; Cooper et al. 2003):

$$
\max p_{1} y_{1, o}+\ldots+p_{n} y_{n, o}
$$

subject to:

$$
\begin{aligned}
& c_{1} x_{1, o}+\ldots c_{m} x_{m, o}=1 \\
& p_{1} y_{1, k}+\ldots+p_{n} y_{n, k}-c_{1} x_{1, k}-\ldots-c_{m} p_{m, k} \leq 0(k=1 \ldots s) \\
& c_{1}, c_{2}, \ldots c_{m} \geq 0 \\
& p_{1}, p_{2}, \ldots p_{n} \geq 0
\end{aligned}
$$

The input orientated BCC model [3] has following form (Banker et al. 1984; Cooper et al. 2003), where $p_{o}$ is the variable allowing identification of the nature of the returns of scale. This model does not predetermine if the value of this variable is positive (increasing returns) or is negative (decreasing returns): 


$$
\max p_{1} y_{1, o}+\ldots+p_{n} y_{n, o}-p_{o}
$$

subject to:

$$
\begin{aligned}
& c_{1} x_{1, o}+\ldots c_{m} x_{m, o}=1 \\
& p_{1} y_{1, k}+\ldots+p_{n} y_{n, k}-c_{1} x_{1, k}-\ldots-c_{m} p_{m, k}-p_{o} \leq 0(k=1 \ldots s) \quad \text { [3] } \\
& c_{1}, c_{2}, \ldots c_{m} \geq 0 \\
& p_{1}, p_{2}, \ldots p_{n} \geq 0
\end{aligned}
$$

The outcome of DEA models is an efficiency score equals to one for efficient units and less than one for inefficient units. So, for inefficient units a ranking is given but for efficient ones no ranking can be given (Azizi et al. 2007). In non-parametric methods many units are calculated as efficient. To rank the relative efficient units, Andersen \& Petersen (1993) developed a modified DEA model. Basic idea of this model is the exclusion of the evaluated unit from the analysis, it is excluded from the constrains. The unit under evaluation is being compared with linear combination of all other analysed units and efficiency can be higher than one (so called "superefficiency"). Modified model from Andersen \& Petersen (1993) is otherwise identical with CCR-and BCC-model. More detail reviews of the DEA methodology are presented by Charnes et al. 1978; Banker et al. 1984; Seiford \& Trall 1990; Ali \& Seiford 1993; Cooper et al. 2003; Sengupta 2003.

Determining appropriate returns to scale is crucial for logging businesses to retain and enhance their competitiveness. Evidence regarding the nature of returns to scale in logging industry is mixed. Several studies suggested increasing returns to scale in this industry, whereas others indicated decreasing returns to scale. However, literature on returns to scale in the logging industry is limited (Stuart et al. 2010). Therefore both, the CCR- and the BCC-models were applied in this analysis to decompose the total efficiency and to evaluate the scale efficiency. The input-oriented models have been chosen, because inputs can be altered by management decisions and it is more difficult at outputs in forestry.

The calculation of the overall efficiency was performed by using computer program EMS. This program is able to compute the overall efficiency by input-, outputand non-orientated DEA models under assumption of constant, variable, non-increasing and non-decreasing return to scale (Scheel 2000). It is also able to compute the superefficiency via a modified model from Andersen \& Petersen (1993). Overall efficiency of individual countries was further analysed according to other into analysis not included variables such as state of the economy and regional characteristics. This process is known as two stage approach (Timmer 1971).

\subsection{Statistical testing of differences in efficiency}

Testing of efficiency differences between the single groups of the countries was carried out by non-parametric statistical tests, because sample size was less than 50 and these tests do not require normal distribution function.
Their disadvantage is the lower power of the statistical test. Statistical testing of difference significance was done by Mann-Whitney U test (in case of two independent interval and binary variables) and by Kruskal-Wallis test (in case of independent interval and nominal variables) ${ }^{1}$.

Null hypothesis (there are no differences between the samples to be tested) and alternative hypothesis (there are significant differences in efficiency of the samples) were defined. Significant level was $\alpha=0.05$. If the $p$ value was less than the chosen significance level, then the null hypothesis was rejected and the alternative hypothesis was accepted. Statistical tests were done by program Statistika CZ, version 9.

\subsection{Models being proposed}

One basic and two modified models (labour and wood sale) were proposed, based on available input and output data. The task of the basic model was an overall efficiency comparison of input-output transformation. All variables are recorded in monetary units and as the inputs were chosen: intermediate consumption $\left(I_{1}\right)$, compensation of employees $\left(I_{2}\right)$, fixed capital consumption, other taxes on production, interests and rents paid $\left(I_{3}\right)$, and as the output: total output of the forestry, other subsidies on production and interest receivable $(O)$.

Labour input is still important indicator of forestry intensity, therefore the labour model was proposed, where the input $\left(I_{2}\right)$ was recorded in technical units (number of employees). Through comparison of the basic model to the labour model, the labour productivity in technical units partially can be assessed and we can respond to the question of the influence of the staff compensation on the efficiency in individual countries.

In the wood sale model the output were divided into two parts: revenues from wood sale $\left(O_{1}\right)$ and other revenues $\left(\mathrm{O}_{2}\right)$. In first variant [wood sale model 1] the wood sale was expressed in cubic metres and in the second variant [wood sale model 2] all variables were recorded in monetary units. Based on comparison of these two variants, the question of successful timber trade can be valuated.

\subsection{Data source}

The results of Integrated Environmental and Economic Accounts for Forests (IEEAF) from Eurostat database were used as a data source. The question is whether all countries applied the rules of IEEAF; therefore the data was transformed according to rules of Economic Accounts for Forestry (EAF). The sample size was 22 countries (as decision making units) and data for 2005-

\footnotetext{
${ }^{1}$ According to the type of variables it is possible to use One-Way ANOVA, but for non-normal data it is more suitable to use also nonparametric tests such as Kruskal-Waliss H test (Rimarčík 2007).
} 
Table 1. Main features of variables included in the analysis.

\begin{tabular}{|c|c|c|c|c|c|}
\hline Variable & Unit & Mean & Standard deviation & Min & Max \\
\hline Intermediate consumption & (€/hectare) & 104.88 & 90.06 & 5.56 & 317.36 \\
\hline Average labour input & (No. of empl./ 1000 hectares) & 5.49 & 4.41 & 0.71 & 20.86 \\
\hline Compensation of employees & $(€ /$ hectare) & 64.98 & 53.30 & 5.04 & 214.34 \\
\hline $\begin{array}{l}\text { Fixed capital consumption, other taxes on production, interests and } \\
\text { rents paid }\end{array}$ & (€/hectare) & 32.56 & 30.62 & 0.12 & 125.30 \\
\hline Total output of the forestry & (€/hectare) & 234.63 & 168.79 & 22.95 & 535.80 \\
\hline Wood sale & $\left(\mathrm{m}^{3} /\right.$ hectare $)$ & 3.36 & 1.74 & 0.33 & 6.74 \\
\hline Revenues from wood sale & (€/hectare) & 138.70 & 97.94 & 8.73 & 383.82 \\
\hline Other revenues & (€/hectare) & 95.94 & 117.09 & 4.74 & 474.45 \\
\hline
\end{tabular}

2008 was processed. All monetary values were expressed in euros; therefore no transformation from national currencies to euros was needed. Of course it is necessary to take in account the limited validity and consistency of the data, which may restrict the significance of results. Within the efficiency assessment in forestry is needed to avoid the extreme values and to include required number of units to be evaluated. Therefore five-year averages from 2005 to 2008 were calculated for each input and output variables. In this way, the value variation typical for the forestry sector was eliminated through the calculation of the mean, whereby the financial data were corrected by the country specific inflation (Harmonised Index of Consumer Prices - HICP) before calculating mean value. All input's and output's values were reduced by extension of the forests available for wood supply - FAWS (European Commission 2009). In this way, it is possible to compare this data per hectare as well as other indicators of IEEAF or EAF directly. Input data files were prepared in MS Excel. Main features of the variables included in the analysis are presented in Table 1.

\section{Results}

\subsection{Results of the basic model}

By the CCR model, the average technical efficiency is 76.51\%: Efficient countries are: Austria, Bulgaria, Finland, Greece, Hungary, Poland, Sweden and Spain. By the BCC model, these countries are also efficient: Switzerland, Germany, Italy, Netherlands and Czech Republic. The average efficiency is $85.47 \%$. When applying the BCC model, more countries are efficient meaning that the models with variable returns to scale do systematically yield higher scores in comparison to the models under assumption of constant return to scale. Average scale efficiency is $82 \%$ (Table 2 ).
Table 2. Efficiency of the forestry in European countries - basic model.

\begin{tabular}{lcccccc}
\hline \multicolumn{1}{c}{ Country } & CCR & R & BCC & R & SE & RTS \\
\hline Slovakia & $54.35 \%$ & 18 & $62.68 \%$ & 19 & $86.71 \%$ & DRS \\
Austria & $100 \%$ & 7 & $100 \%$ & 7 & $100 \%$ & CRS \\
Bulgaria & $100 \%$ & 4 & $100 \%$ & 8 & $100 \%$ & CRS \\
Switzerland & $47.30 \%$ & 20 & $100 \%$ & 1 & $47.30 \%$ & DRS \\
Cyprus & $23.16 \%$ & 22 & $31.72 \%$ & 22 & $73.01 \%$ & IRS \\
Germany & $68.95 \%$ & 14 & $100 \%$ & 13 & $68.95 \%$ & DRS \\
Finland & $100 \%$ & 6 & $100 \%$ & 10 & $100 \%$ & CRS \\
France & $60.08 \%$ & 16 & $63.11 \%$ & 18 & $95.20 \%$ & DRS \\
Greece & $100 \%$ & 3 & $100 \%$ & 3 & $100 \%$ & CRS \\
Hungary & $100 \%$ & 2 & $100 \%$ & 4 & $100 \%$ & CRS \\
Italy & $99.95 \%$ & 9 & $100 \%$ & 12 & $99.95 \%$ & IRS \\
Lithuania & $65.07 \%$ & 15 & $65.56 \%$ & 17 & $99.25 \%$ & IRS \\
Netherlands & $57.76 \%$ & 17 & $100 \%$ & 9 & $57.76 \%$ & DRS \\
Norway & $69.79 \%$ & 13 & $78.01 \%$ & 16 & $89.46 \%$ & IRS \\
Portugal & $85.05 \%$ & 10 & $88.77 \%$ & 14 & $95.81 \%$ & DRS \\
Romania & $53.62 \%$ & 19 & $55.26 \%$ & 21 & $97.03 \%$ & DRS \\
Slovenia & $78.62 \%$ & 11 & $79.37 \%$ & 15 & $99.06 \%$ & IRS \\
Great Britain & $41.66 \%$ & 21 & $55.84 \%$ & 20 & $74.61 \%$ & DRS \\
Poland & $100 \%$ & 1 & $100 \%$ & 2 & $100 \%$ & CRS \\
Czech Republic & $77.81 \%$ & 12 & $100 \%$ & 6 & $77.81 \%$ & DRS \\
Sweden & $100 \%$ & 8 & $100 \%$ & 11 & $100 \%$ & CRS \\
Spain & $100 \%$ & 5 & $100 \%$ & 5 & $100 \%$ & CRS \\
\hline
\end{tabular}

Where: CCR - efficiency by the CCR-model, R - ranking based on superefficiency, BCC - efficiency by the BCC-model, SE - scale efficiency, RTS - return to scale, DRS - decreasing returns to scale, IRS - increasing returns to scale, CRS - constant returns to scale.

\subsection{Target values}

As it was mentioned, Data Envelopment analysis is based on linear programming and this fact allows of calculating the target values of inputs (in case of input orientated models) or outputs (in case of output orientated models) for each inefficient DMU. Target values for Slovakia are shown in Table 3. From the target values follows that all inputs should be lowered about $46 \%$ according to CCR- model and about $36 \%$ according to BCC-model to be efficient. It means the reducing the labour cost from 128 mil.€ to app. 64 mil.€, or to app. 64 mil.€, respectively.

Table 3. Target values of inputs for Slovakia by basic model.

\begin{tabular}{lcccc}
\hline & $\mathrm{I}_{1}$ & $\begin{array}{c}\mathrm{I}_{2} \\
€ / \text { hectare }\end{array}$ & $\mathrm{I}_{3}$ & $\begin{array}{c}\text { Efficiency } \\
\%\end{array}$ \\
\hline Actual values & 135.0 & 77.5 & 52.1 & - \\
Target values by CCR model & 73.4 & 42.3 & 28.4 & 54.35 \\
Change in \% & -46 & -46 & -46 & - \\
Target values by BCC model & 86.6 & 49.5 & 33.1 & 62.68 \\
Change in \% & -36 & -36 & -36 & - \\
\hline
\end{tabular}

Where: $I_{1}$ - intermediate consumption; $I_{2}$ - compensation of employees; $I_{3}$ - fixed capital consumption, other taxes on production, interests and rents paid. 


\subsection{Labour productivity}

Labour input is still important indicator of forestry intensity and also consequential cost item. Labour cost and number of employees per hectare vary in evaluated countries.

If we compare results of basic and labour model, it is possible to consider labour productivity and level of employee's compensation in individual countries. In general, labour productivity is measured as a ratio of output to the labour input (hour worked, numbers of employees or labour cost). Based on this comparison it is feasible to divide the countries into three groups. In first group are the countries, in which the technical productivity of labour is higher than economic; it means compensation of employees influences the efficiency negatively and do not correspond to technical productivity of labour. Switzerland, Germany, Netherlands, United Kingdom and Czech Republic are included in the first group. In the second group, the technical and economic labour productivity are the same. In this group are Cyprus, Finland, Greece, Italy, Poland Sweden and Spain. The third group is created from countries, in which the efficiency of the technical model is lower than economic model and it means there is room for higher wages at the comparable efficiency level. It is the biggest group: Slovakia, Austria, Bulgaria, France, Hungary, Lithuania, Norway, Portugal, Romania and Slovenia. Countries with economy in transition (except Poland and Czech Republic) belong to the third group.

\subsection{Wood sale}

Forestry receives majority of its incomes from the sale of wood and timber in most countries. The share of income from timber sales in this sample is around $76 \%$ and there are great differences in single countries. The share ranges from $53 \%$ in Netherlands to $95 \%$ in Lithuania. Based on results of this model and its variants, the question of successful timber trade can be valuated.

\subsection{Efficiency according to the regional typology}

Individual countries have different conditions concerning production characteristics (forest characteristics, forest types, intensity of production regimes, technology and so on), consumption characteristics (type and size of industry), general regional characteristics and other political, environmental, and social factors (Rametsteiner et al. 2006). They introduce and more in detail describe 7 regional types: globalized regions (Nordic-Baltic region), wood production oriented regions (Central Europe), plantation-oriented regions (Western Europe), broader, multifunctional forestry oriented regions (Western Europe), urban society service influenced regions (North-western Europe), countries in transition (Eastern Europe), low forest management intensity regions (Southern Europe).

Table 4. Efficiency of the forestry in European countries - labour model.

\begin{tabular}{|c|c|c|c|c|c|c|c|c|c|c|}
\hline \multirow{2}{*}{ Country } & \multicolumn{5}{|c|}{ Technical variant } & \multicolumn{5}{|c|}{ Economic variant } \\
\hline & CCR & $\mathrm{R}$ & $\mathrm{BCC}$ & $\mathrm{R}$ & SE & CCR & $\mathrm{R}$ & $\mathrm{BCC}$ & $\mathrm{R}$ & SE \\
\hline Slovakia & $44.13 \%$ & 17 & $62.51 \%$ & 16 & $70.60 \%$ & $54.35 \%$ & 18 & $62.68 \%$ & 19 & $86.71 \%$ \\
\hline Austria & $83.97 \%$ & 9 & $100.00 \%$ & 5 & $83.97 \%$ & $100.00 \%$ & 7 & $100.00 \%$ & 7 & $100.00 \%$ \\
\hline Bulgaria & $38.76 \%$ & 20 & $43.17 \%$ & 19 & $89.78 \%$ & $100.00 \%$ & 4 & $100.00 \%$ & 8 & $100.00 \%$ \\
\hline Switzerland & $52.44 \%$ & 15 & $100.00 \%$ & 1 & $52.44 \%$ & $47.30 \%$ & 20 & $100.00 \%$ & 1 & $47.30 \%$ \\
\hline Cyprus & $23.16 \%$ & 22 & $31.72 \%$ & 22 & $73.01 \%$ & $23.16 \%$ & 22 & $31.72 \%$ & 22 & $73.01 \%$ \\
\hline Germany & $90.73 \%$ & 7 & $100.00 \%$ & 11 & $90.73 \%$ & $68.95 \%$ & 14 & $100.00 \%$ & 13 & $68.95 \%$ \\
\hline Finland & $100.00 \%$ & 5 & $100.00 \%$ & 8 & $100.00 \%$ & $100.00 \%$ & 6 & $100.00 \%$ & 10 & $100.00 \%$ \\
\hline France & $58.85 \%$ & 14 & $65.15 \%$ & 14 & $90.33 \%$ & $60.08 \%$ & 16 & $63.11 \%$ & 18 & $95.20 \%$ \\
\hline Greece & $100.00 \%$ & 3 & $100.00 \%$ & 3 & $100.00 \%$ & $100.00 \%$ & 3 & $100.00 \%$ & 3 & $100.00 \%$ \\
\hline Hungary & $35.52 \%$ & 21 & $38.74 \%$ & 21 & $91.69 \%$ & $100.00 \%$ & 2 & $100.00 \%$ & 4 & $100.00 \%$ \\
\hline Italy & $99.95 \%$ & 6 & $100.00 \%$ & 10 & $99.95 \%$ & $99.95 \%$ & 9 & $100.00 \%$ & 12 & $99.95 \%$ \\
\hline Lithuania & $42.34 \%$ & 19 & $42.38 \%$ & 20 & $99.91 \%$ & $65.07 \%$ & 15 & $65.56 \%$ & 17 & $99.25 \%$ \\
\hline Netherlands & $85.59 \%$ & 8 & $100.00 \%$ & 7 & $85.59 \%$ & $57.76 \%$ & 17 & $100.00 \%$ & 9 & $57.76 \%$ \\
\hline Norway & $58.88 \%$ & 13 & $88.92 \%$ & 12 & $66.22 \%$ & $69.79 \%$ & 13 & $78.01 \%$ & 16 & $89.46 \%$ \\
\hline Portugal & $63.56 \%$ & 11 & $88.77 \%$ & 13 & $71.60 \%$ & $85.05 \%$ & 10 & $88.77 \%$ & 14 & $95.81 \%$ \\
\hline Romania & $48.17 \%$ & 16 & $55.26 \%$ & 18 & $87.17 \%$ & $53.62 \%$ & 19 & $55.26 \%$ & 21 & $97.03 \%$ \\
\hline Slovenia & $62.97 \%$ & 12 & $64.12 \%$ & 15 & $98.21 \%$ & $78.62 \%$ & 11 & $79.37 \%$ & 15 & $99.06 \%$ \\
\hline Great Britain & $43.09 \%$ & 18 & $55.84 \%$ & 17 & $77.17 \%$ & $41.66 \%$ & 21 & $55.84 \%$ & 20 & $74.61 \%$ \\
\hline Poland & $100.00 \%$ & 1 & $100.00 \%$ & 2 & $100.00 \%$ & $100.00 \%$ & 1 & $100.00 \%$ & 2 & $100.00 \%$ \\
\hline Czech republic & $78.63 \%$ & 10 & $100.00 \%$ & 9 & $78.63 \%$ & $77.81 \%$ & 12 & $100.00 \%$ & 6 & $77.81 \%$ \\
\hline Sweden & $100.00 \%$ & 4 & $100.00 \%$ & 6 & $100.00 \%$ & $100.00 \%$ & 8 & $100.00 \%$ & 11 & $100.00 \%$ \\
\hline Spain & $100.00 \%$ & 2 & $100.00 \%$ & 4 & $100.00 \%$ & $100.00 \%$ & 5 & $100.00 \%$ & 5 & $100.00 \%$ \\
\hline
\end{tabular}

Where: CCR - efficiency by the CCR-model, R - ranking based on superefficiency, BCC - efficiency by the BCC-model, SE - scale efficiency, RS - return to scale, DRS - decreasing returns to scale, IRS - increasing returns to scale, CRS - constant returns to scale. 
Table 5. Efficiency of the forestry in European countries - wood sale model.

\begin{tabular}{|c|c|c|c|c|c|c|c|c|c|c|}
\hline \multirow{2}{*}{ Country } & \multicolumn{5}{|c|}{ Technical variant } & \multicolumn{5}{|c|}{ Economic variant } \\
\hline & CCR & $\mathrm{R}$ & $\mathrm{BCC}$ & $\mathrm{R}$ & SE & CCR & $\mathrm{R}$ & $\mathrm{BCC}$ & $\mathrm{R}$ & SE \\
\hline Slovakia & $55.73 \%$ & 18 & $78.29 \%$ & 18 & $71.18 \%$ & $62.17 \%$ & 17 & $69.48 \%$ & 18 & $89.48 \%$ \\
\hline Austria & $85.09 \%$ & 13 & $100.00 \%$ & 10 & $85.09 \%$ & $100.00 \%$ & 7 & $100.00 \%$ & 1 & $100.00 \%$ \\
\hline Bulgaria & $100.00 \%$ & 5 & $100.00 \%$ & 7 & $100.00 \%$ & $100.00 \%$ & 5 & $100.00 \%$ & 9 & $100.00 \%$ \\
\hline Switzerland & $51.92 \%$ & 20 & $69.42 \%$ & 19 & $74.79 \%$ & $53.00 \%$ & 20 & $100.00 \%$ & 2 & $53.00 \%$ \\
\hline Cyprus & $25.59 \%$ & 22 & $43.09 \%$ & 22 & $59.39 \%$ & $24.78 \%$ & 22 & $43.09 \%$ & 22 & $57.51 \%$ \\
\hline Germany & $61.40 \%$ & 17 & $100.00 \%$ & 12 & $61.40 \%$ & $78.52 \%$ & 15 & $100.00 \%$ & 12 & $78.52 \%$ \\
\hline Finland & $100.00 \%$ & 10 & $100.00 \%$ & 13 & $100.00 \%$ & $100.00 \%$ & 9 & $100.00 \%$ & 13 & $100.00 \%$ \\
\hline France & $55.02 \%$ & 19 & $59.25 \%$ & 21 & $92.86 \%$ & $61.33 \%$ & 18 & $63.42 \%$ & 19 & $96.70 \%$ \\
\hline Greece & $100.00 \%$ & 4 & $100.00 \%$ & 4 & $100.00 \%$ & $100.00 \%$ & 4 & $100.00 \%$ & 6 & $100.00 \%$ \\
\hline Hungary & $100.00 \%$ & 2 & $100.00 \%$ & 5 & $100.00 \%$ & $100.00 \%$ & 2 & $100.00 \%$ & 7 & $100.00 \%$ \\
\hline Italy & $97.79 \%$ & 11 & $100.00 \%$ & 14 & $97.79 \%$ & $100.00 \%$ & 11 & $100.00 \%$ & 14 & $100.00 \%$ \\
\hline Lithuania & $100.00 \%$ & 8 & $100.00 \%$ & 11 & $100.00 \%$ & $91.81 \%$ & 12 & $100.00 \%$ & 15 & $91.81 \%$ \\
\hline Netherlands & $100.00 \%$ & 9 & $100.00 \%$ & 1 & $100.00 \%$ & $100.00 \%$ & 10 & $100.00 \%$ & 3 & $100.00 \%$ \\
\hline Norway & $76.04 \%$ & 15 & $84.23 \%$ & 16 & $90.28 \%$ & $71.51 \%$ & 16 & $78.15 \%$ & 17 & $91.50 \%$ \\
\hline Portugal & $100.00 \%$ & 7 & $100.00 \%$ & 8 & $100.00 \%$ & $100.00 \%$ & 8 & $100.00 \%$ & 10 & $100.00 \%$ \\
\hline Romania & $71.71 \%$ & 16 & $100.00 \%$ & 15 & $71.71 \%$ & $55.51 \%$ & 19 & $61.87 \%$ & 20 & $89.72 \%$ \\
\hline Slovenia & $81.73 \%$ & 14 & $81.86 \%$ & 17 & $99.84 \%$ & $87.98 \%$ & 14 & $93.28 \%$ & 16 & $94.32 \%$ \\
\hline Great Britain & $42.63 \%$ & 21 & $59.93 \%$ & 20 & $71.13 \%$ & $41.83 \%$ & 21 & $57.51 \%$ & 21 & $72.74 \%$ \\
\hline Poland & $100.00 \%$ & 1 & $100.00 \%$ & 3 & $100.00 \%$ & $100.00 \%$ & 1 & $100.00 \%$ & 5 & $100.00 \%$ \\
\hline Czech Republic & $86.88 \%$ & 12 & $100.00 \%$ & 2 & $86.88 \%$ & $89.56 \%$ & 13 & $100.00 \%$ & 4 & $89.56 \%$ \\
\hline Sweden & $100.00 \%$ & 6 & $100.00 \%$ & 9 & $100.00 \%$ & $100.00 \%$ & 6 & $100.00 \%$ & 11 & $100.00 \%$ \\
\hline Spain & $100.00 \%$ & 3 & $100.00 \%$ & 6 & $100.00 \%$ & $100.00 \%$ & 3 & $100.00 \%$ & 8 & $100.00 \%$ \\
\hline
\end{tabular}

Where: CCR - efficiency by the CCR-model, R - ranking based on superefficiency, BCC - efficiency by the BCC-model, SE - scale efficiency, RS - returns to scale, DRS - decreasing returns to scale, IRS - increasing returns to scale, CRS - constant returns to scale.

For purposes of this analysis, some regional types were integrated and slightly modified. Four groups were created based on this typology and the countries assigned: 1. regions dominated by restitution issues "countries in transition" ${ }^{2}$, regions dominated by low forest management intensity and with high importance of non-wood forest products ${ }^{3}$, regions with multifunctional forestry ${ }^{4}$, production regions based on plantations and globalized pulp and paper industry-orientated countries ${ }^{5}$. In this case non-parametric test for independent groups (Kruskal-Wallis H test) was used. The initial view would indicate that it is possible to see differences among individual groups, but they are not statistically significant in all cases. The most efficient were countries with low management intensity in basic and labour model and pulp and paper industry-orientated countries in wood sale models (Table 6).

\subsection{Efficiency according to the state of economy}

Another possibility is to divide the countries according to the state of their economy, into advanced countries and countries with economy in transition and then to analyse efficiency. In comparison of descriptive characteristics (mean, median, standard deviation, range and skewness) it is also possible to see differences (Table 7). The differences were not statistically significant in all models at the significant level $\alpha=0.05$, except labour model and efficiency by BBC-model $(p=0.048)$.

Table 6. Differences in efficiency among individual groups of countries.

\begin{tabular}{|c|c|c|c|c|c|}
\hline Efficiency-CCR model & $\mathrm{n}$ & Basic model & Labour model & Wood sale model 1 & Wood sale model 2 \\
\hline Countries in transition & 5 & 81.59 & 53.32 & 85.49 & 83.54 \\
\hline Countries with low management intensity & 5 & 81.63 & 77.33 & 84.68 & 84.96 \\
\hline Countries with multifunctional forestry & 4 & 63.54 & 70.16 & 63.81 & 70.60 \\
\hline Pulp and paper industry-orientated countries & 8 & 76.61 & 72.11 & 85.69 & 86.64 \\
\hline$H(3, n=22)$ & & 2.12 & 2.72 & 3.92 & 3.58 \\
\hline$p$ value & & 0.547 & 0.437 & 0.271 & 0.311 \\
\hline Efficiency-BCC model & $\mathrm{n}$ & Basic model & Labour model & Wood sale model 1 & Wood sale model 2 \\
\hline Countries in transition & 5 & 83.59 & 59.94 & 95.66 & 86.27 \\
\hline Countries with low management intensity & 5 & 84.10 & 84.10 & 88.62 & 88.62 \\
\hline Countries with multifunctional forestry & 4 & 90.78 & 91.29 & 82.17 & 90.86 \\
\hline Pulp and paper industry-orientated countries & 8 & 84.85 & 81.41 & 90.75 & 91.12 \\
\hline$H(3, n=22)$ & & 0.50 & 4.23 & 1.35 & 0.32 \\
\hline$p$ value & & 0.919 & 0.237 & 0.718 & 0.956 \\
\hline
\end{tabular}

Where: wood sale model 1 - technical variant, wood sale model 2 - economic variant.

${ }^{2}$ Slovakia, Hungary, Romania, Bulgaria, Poland.

${ }^{3}$ Greece, Italy, Spain, Portugal, Cyprus.

${ }^{4}$ Germany, France, Switzerland, Czech Republic.

${ }^{5}$ Finland, Sweden, Norway, United Kingdom, Netherlands, Austria, Slovenia. 
Table 7. Differences in efficiency according to the state of economy.

\begin{tabular}{|c|c|c|c|c|c|}
\hline Efficiency-CCR model & $\mathrm{n}$ & Basic model & Labour model & Wood sale model 1 & Wood sale model 2 \\
\hline Countries in transition & 8 & 78.68 & 56.32 & 87.01 & 85.88 \\
\hline Advanced countries & 14 & 75.26 & 75.73 & 78.25 & 80.78 \\
\hline$p$ value & & 0.811 & 0.076 & 0.495 & 0.946 \\
\hline Efficiency-BCC model & $\mathrm{n}$ & Basic model & Labour model & Wood sale model 1 & Wood sale model 2 \\
\hline Countries in transition & 8 & 82.86 & 63.27 & 95.02 & 90.58 \\
\hline Advanced countries & 14 & 86.96 & 87.89 & 86.85 & 88.73 \\
\hline$p$ value & & 0.585 & 0.048 & 0.539 & 0.891 \\
\hline
\end{tabular}

Where: wood sale model 1 - technical variant, wood sale model 2 - economic variant.

\section{Discussion}

Experience with application of DEA has shown that tcan be appropriate approach to efficiency evaluation and an alternative and completing method for performance measurements using other methods and approaches also. Obtained results show average efficiency in range of 69 - $90 \%$ (depending on the model). It was comparable to those in similar analysis using DEA in wood-based industry (Yin 1998, 1999; Kao 2000; Nyrud \& Baardsen 2003; Diaz-Balteiro et al. 2006).

This paper is based on the best available data, but there are still uncertainties. Especially the limited validity and consistency of the data may restrict the significance of the results and it is also questionable to what extend are the national methodologies in applying either the Economic Accounts for Forestry or Integrated Environmental and Economic Accounts for Forests and their practical rules. Main problem of applying either the system of Economic Accounts for Forestry or system of Integrated Environmental and Economic Accounts for Forests is data availability at national level.

According to the first group, efficiency results are probably influenced by high social and health fund contribution and the resulting higher labour cost. Other reasons for differences between technical and economic models could be the insufficient application of new ecological technologies, small-scale forest ownership and the resulting effective forest property management, and so on. Important factor could be also the amount of intermediate consumption, in which various shares of forestry services in individual countries could be included.

The efficiency of the groups created according to regional classification is comparable to the index of globalization estimated by Rametsteiner et al. (2006), which was lowest in "countries in transition" and similar in other groups.

\section{Conclusions}

The purpose of this study was to determine to what extend the efficiency of Slovak forestry is different in comparison to other European countries. Based on the efficiency analysis, the following results can be concluded:
- There are great differences in efficiency among individual countries; it could be caused by different approaches to forest management, providing of forest services to public, supporting of forestry, share of public ownership, policy goals and other realities.

- Based on the results of the labour model it is feasible to divide the countries into three groups: in first group was the compensation of employees higher than the technical productivity of labour, in the second group these factors were the same or similar and in the third one was room for higher wages at the comparable efficiency.

- The state of economy (advanced countries and countries with economy in transition) and region do not have statistically significant influence on efficiency.

- Slovak forestry has achieved less than average efficiency in comparison to other European countries; main causes are probably: obsolete technologies, machines and devices used, lower utilization of harvestor technologies, lower support from public sources, environmental and natural conditions, but on the other hand lower wages in Slovak forestry than in most EU countries influenced the efficiency in a positive way.

All conclusions are based on simplified analysis and valid for this sample. The results can be different for another sample size. It is connected with the main disadvantages of this method, which are: inclusion or exclusion of variables can affect the results significantly, the number of efficient firms on the frontier tends to increase with the number of inputs and output variables, Such analysis can be extended and modified according to specific conditions and requests.

\section{Acknowledgment}

This work was supported by the Slovak Research and Development Agency under research project "APVV-15-0487 Research on efficiency of forestry services outsourcing". Author would like to thank Prof. Walter Sekot for his very useful comments. The author also would like to acknowledge the valuable comments provided by the reviewers of this manuscript which led to substantial improvement of the analysis. 


\section{References}

Ali, A. I., Seiford, L. M., 1993: The Mathematical Programming Approach to Efficiency Analysis. In: Fried, A. O., Lovell, C. A:K., Schmidt, S. S. (eds):The Measurement of Productive Efficiency, Techniques and Applications, Oxford University Press, New York, p. $120-159$.

Andersen, P., Petersen, N. C., 1993: A procedure for ranking efficient units in data envelopment analysis. Management Science, 39:1261-1271.

Azizi, K. H., Lofti, F. H, Saati, S., Vahidi, A. R., 2007: Ranking the Electricity Producer Companies in View of Manpower Efficiency by DEA. Applied Mathematical Sciences, 1:761-768.

Banker, R. D., Charnes, A., Cooper, W. W., 1984: Some models for estimating technical and scale inefficiency in data envelopment analysis. Management Science, 30:1078-1092.

Bogetoft, P., Thorsen, J., Strange, N., 2003: Efficiency and merger gains in the Danish Forestry Extension Service. Forest Science, 49:585-595.

Charnes, A., Cooper, W.W., Rhodes, E., 1978: Measuring the Efficiency of Decision Making Units. European Journal of Operational Research, 3:429-444.

Cooper, W. W., Seiford, L. M., Tone, K., 2003: Data Envelopment Analysis: a Comprehensive text with Models, Applications, References and DEA-Solver Software. Kluwer Academic Publ., Boston, 318 p.

Diaz-Balteiro, L., Herruzo, A. C., Mertinez, M., Pachón, J. G., 2006: An analysis of productive efficiency and innovation activity using DEA: An application to Spain's wood-based industry. Forest Policy and Economics, 8:762-773.

European Commission, 2009: Forestry statistics, Eurostat Pocketbooks 2009 Edition, Luxembourg: Publications Office of the European Union, $172 \mathrm{p}$.

Hanninen, H., Viitala, E. J., 1998: Efficiency of Nonprofit Forestry Extension Services: An Application of DEA. Finish Forest Research Institute.

Hoffmann, Ch., 2006: Die Data Envelopment Analysis (DEA) und ihre Anwendungsmöglichkeiten zur vergleichenden Effizienzanalyse im Forstwesen, University of Natural Resources and Applied Life Sciences in Vienna, Dissertation, 299 p.

Hoffmann, Ch., Sekot, W., 2004:Anwendungspotentiale der Data Envelopment Analysis (DEA) zur Effizienzbewertung in der Forstwirtschaft. Zwischenbericht zum Projekt, University of Natural Resources and Applied Life Sciences in Vienna, 20 p.

Kao, C., 2000: Measuring the Performance Improvement of Taiwan Forests after Reorganization. Forest Science, 46:577-584.

Kao, C., Yang, Y. C., 1991: Measuring the Efficiency of Forest Management. Forest Science, 37:1239-1252.

Kao, C., Yang, Y. C., 1992: Reorganization of forest districts via efficiency measurement. European Journal of Operational Research, 58:356-362.
Kovalčík, M., 2007. Porovnanie efektívnosti lesných podnikov podla Data Envelopment Analysis a Cost Benefit Analysis (Comparison of forest enterprises efficiency by using Data Envelopment Analysis and Cost Benefit Analysis). In: Financovanie 2007 Lesy - Drevo, Proceedings from international conference, Technical university Zvolen, $7 \mathrm{p}$.

Le Bel, L., 1996: Performance and efficiency evaluation of logging contractors using Data Envelopment Analysis. Blacksburg, VA: Virginia Polytechnic and State University. Dissertation, 201 p.

LeBel, L. G., Stuart, W. B., 1998. Technical efficiency evaluation of logging contractors using a nonparametric model. Journal of Forest Engineering, 9:1524.

Liu, Ch., 2005: Measuring the relative efficiency and reorganization-The example of CDFAs of the NAN-TOU County in Taiwan, Economics Bulletin, 17:1-11.

Nyrud, A., Baardsen, S., 2003: Production efficiency and productivity growth in Norwegian sawmilling. Forest Science, 49:89-97.

Oesten, G., Roeder, A., 2001: Management von Forstbetrieben. Band 1, Verlag Dr. Kessel, Freiburg, 365 p.

Rametsteiner, E., Nilsson, S., Böttcher, H., Havlik, P., Kraxner, F., Leduc, S.et al., 2006: Study of the Effects of Globalization on the Economic Viability of EU Forestry. EC Contract No.30-CE-009757/00-89, International Institute for Applied Systems Analysis, $198 \mathrm{p}$.

Rimarčík, M., 2007: Štatistika pre prax. 200 p.

Saastamoinen, O., Matero, J., 2006: Introduction to forestry, forest policy and economics. University of Joensuu, 93 p.

Scheel, H., 2000: Effizienzmaße der Data Envelopment Analysis. Deutscher Universitätsverlag, Gabler Edition Wissenschaft, Wiesbaden, 183 p.

Schefczyk, M., Gerpott, T. J., 1994: Operativer und Finanzieler Erfolg von LVU. In: Zeitschrift für Betriebswirtschaft, 64:933-957.

Sekot, W., Hoffmann, Ch., 2007: Extension of interfirm comparison of forest enterprises by means of Data Envelopment Analysis. Austrian Journal of Forest Science, 124:37-64.

Sengupta, J. K., 2003: New Efficiencay Theory, with applications of Data Envelopment Analysis. Springer Verlag Berlin Heidelberg, $176 \mathrm{p}$.

Seiford, L. M., Thrall, R. M., 1990: Recent development in DEA: the mathematical programming approach to frontier analysis. Journal of Econometrics, 46:7-38.

Shiba, M., 1997. Measuring the efficiency of managerial and technical performances in forestry activities by means of Data Envelopment Analysis (DEA). Journal of Forest Engineering, 8:7-19.

Sowlati, T., 2005: Efficiency studies in forestry using data envelopment analysis. Forest Products Journal, 55:49-57. 
Timmer, C. P., 1971: Using a Probabilistic Frontier Production to Measure Technical Efficiency. Journal of Political Economy, 79:776-794.

Yin, R., 1998: DEA: A new methodology for evaluating the performance of forest products producers. Forest Production Journal, 48:29-34.
Yin, R., 1999: Production efficiency and cost competitiveness of pulp producers in the Pacific Rim. Forest Production Journal, 49:44-49. 